\title{
Yield and botanical composition of pastures sown under rape into an ex- Pinus radiata forest block
}

\author{
A. MILLS, D.J. MOOT, A. MARSHALL and G.R. EDWARDS. \\ Agriculture and Life Sciences Division, PO Box 84, Lincoln University, Canterbury \\ millsa@lincoln.ac.nz
}

\begin{abstract}
After the removal of Pinus radiata forests, conditions for establishing pastures are often sub optimal. The ability of rape to aid pasture establishment and suppress weeds was investigated at Darfield, Canterbury between November 2005 and February 2007. The strip plot experiment used pasture grass (perennial ryegrass, tall fescue or cocksfoot) as the main plot and rape sowing rate $(0,0.51 .5$ or $3.0 \mathrm{~kg} / \mathrm{ha})$ as the subplot. There was no difference in total pasture yield at the first spring harvest but $50 \%$ of the dry matter yield from pastures sown without rape was from weeds compared with $\leq 10 \%$ in those sown with $\geq 1.5 \mathrm{~kg} / \mathrm{ha}$ of rape. There was no initial yield benefit from rape sown at $3.0 \mathrm{~kg} / \mathrm{ha}$ compared with $1.5 \mathrm{~kg} / \mathrm{ha}$ but rape regrowth was greater from the higher rate. White clover was $58 \%$ of the total legume yield initially but by February 2007 red clover was dominant (70-95\%). In this forestry conversion to pasture, rape sown at $1.5 \mathrm{~kg} / \mathrm{ha}$ reduced weed encroachment particularly for the tall fescue and cocksfoot which are slow establishing dryland species. Keywords: Brassica napus, cover crop, Dactylis glomerata, Festuca arundinacea, forest conversion, Lolium perenne, pasture establishment, Trifolium pratense, $T$. repens, undersowing
\end{abstract}

\section{Introduction}

After forestry blocks are harvested, soils often have a compacted soil structure and low $(<5.0)$ soil $\mathrm{pH}$. Compaction results from mechanical harvesting, including windrowing and stump grinding. These actions destroy aggregate integrity and create fine soil particles prone to wind erosion. Capital fertiliser inputs of sulphur, phosphorus, trace elements and lime can overcome low fertility levels and the rate of increase is affected by the rate and timing of applications (Condron et al. 2007). In Canterbury, forestry plantations were historically sown on marginal land with shallow soils of low water holding capacity.

Following the removal of mature plantation trees, the high light environment encourages weed seed germination when there is adequate soil moisture. Dominant weed species in this environment include perennial species such as gorse (Ulex europaeus), broom (Cytisus scoparius) and sorrel (Rumex acetosella), which are adapted to low pH conditions (Keoghan \& Allan 1992), and the annuals, wireweed (Polygonum aviculare) and fathen (Chenopodium album).

Cover crops, such as barley (Hordeum vulgare) and rape (Brassica napus), can be used to suppress weeds during pasture establishment (Wynn-Williams 1976). Cover crops also increase the economic return in the establishment year by the provision of valuable summer feed and create a microclimate, with reduced wind run, that can aid the establishment of slower emerging species. Cullen (1964) recommended low rates of rape for weed suppression at low fertility sites. Subsequent management should aim, through grazing or cutting, to reduce competition from the oversown species for the benefit of the establishing undersown crop or pasture.

Selection of the appropriate pasture grass depends on the biophysical characteristics of the location. Perennial ryegrass (Lolium perenne) is an aggressive competitor during establishment (Moot et al. 2000) and can be successfully established in most temperate New Zealand conditions. However, both perennial ryegrass and white clover (Trifolium repens) perform poorly when exposed to drought conditions (Korte \& Chu 1983; Baker et al. 1985; Knowles et al. 2003). In dryland conditions on the East Coast of the South Island, both tall fescue (Festuca arundinacea) and cocksfoot (Dactylis glomerata) are successful in environments prone to summer drought conditions (Charton \& Stewart 1999; Stevens \& Hickey 2000). Both of these species are slower to establish than perennial ryegrass, due to higher thermal time requirements for germination and low seedling vigour (Moot et al. 2000). This makes pastures based on them susceptible to invasion from annual and perennial weeds. In this study, the aim was to determine the suitability of rape, sown at different rates, as a cover crop to increase pasture DM yield and suppress weed species during establishment of dryland pastures on forestry land converted to pasture on the Canterbury plains.

\section{Materials and Methods}

This experiment was sown at Darfield, Canterbury within a 30 hectare ex-Pinus radiata forestry block which is part of a forest to pastures conversion process undertaken by the Selwyn Plantation Board Ltd. The third rotation forest was harvested in 2004/2005. Slash was windrowed and burnt in winter. Stump grinding and soil conditioning 
procedures were then used to create a seedbed following a winter fallow. Soil tests were taken prior to pasture establishment and are presented in a separate paper (Condron et al. 2007). A strip plot experiment (Petersen 1985) was sown on 6/10/2005 with three grass species as the main plot strips and replicated four times giving a total of 12 main plot strips. Pasture grasses were 'Meridian' perennial ryegrass $(8 \mathrm{~kg} / \mathrm{ha})$, 'Vulcan' tall fescue $(12 \mathrm{~kg} / \mathrm{ha})$ or 'Vision' cocksfoot $(3 \mathrm{~kg} / \mathrm{ha})$. 'Winfred' rape was sown at four rates $(0,0.5,1.5$ and $3.0 \mathrm{~kg} / \mathrm{ha}$ ) in perpendicular strips across main plots as the sub plot treatment and this resulted in a total of 48 individual sub plots of $40 \mathrm{~m}^{2}(10 \times 4 \mathrm{~m})$.

All main plot grass species were also sown with 3.5 $\mathrm{kg} / \mathrm{ha}$ of 'Demand' white clover, $4 \mathrm{~kg} / \mathrm{ha}$ 'Pawera' red clover (T. pratense), $1 \mathrm{~kg} /$ ha of 'Puna' chicory (Cichorium intybus) and $1 \mathrm{~kg} / \mathrm{ha}$ of 'Lancelot' plantain (Plantago lanceolata). All clover sowing rates are for coated seeds. Environmental conditions were reported by Moot et al. (2007).

The effects of brassica sowing rate and grass species on pasture yield and botanical composition were measured through five regrowth cycles (ending 17/1/2006, 3/5/ 2006, 13/10/2006, 19/12/2006 and 16/2/2007). After each harvest, all plots were grazed in common for a maximum of 2 days with rising 1-year ewes (2500 hoggets/ha) until all grazeable herbage was removed. Sheep broke into the experimental plots in August 2006 and ate the winter regrowth (4/5/2006-4/8/2006) so no measurements were made for this period.

Dry matter production and botanical composition were measured from destructive harvests of $0.2 \mathrm{~m}^{2}$ quadrats on the first two harvest dates (17/1/2006 and 3/5/2006). Samples were sorted for botanical composition (Cayley $\&$ Bird 1996) and dried to constant weight in a forced air

Figure 1 Measured total DM yield (kg DM/ha) against pasture height $(\mathrm{cm})$ from a rising plate meter. The regression was $\mathrm{DM}=$ $234 x\left(R^{2}=0.84\right)$. The form of the separate regression for tall fescue outliers $(X)$ on the $13 / 10 / 2006$ was $D M=49.8 x$.

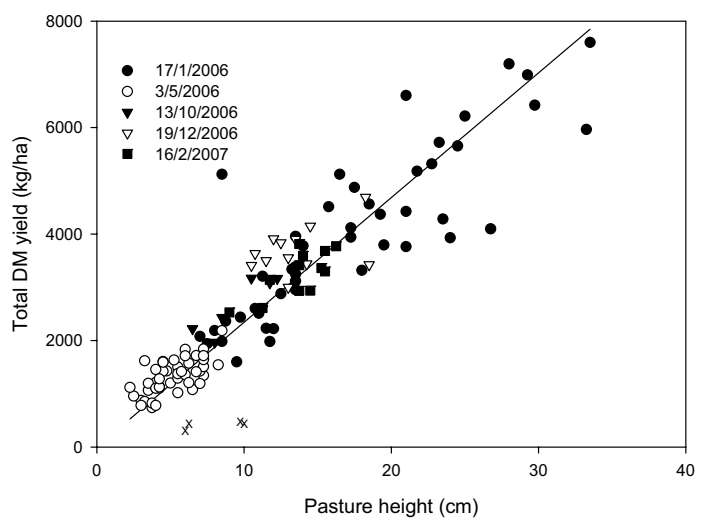

oven at $65^{\circ} \mathrm{C}$. Paired comparisons were made between $\mathrm{DM}$ yield and additional rising plate meter readings taken from the same area to create a calibration for dry matter (DM) measurements for the three subsequent harvests (Fig. 1). The least squares linear regression between compressed pasture height and total DM yield was $\mathrm{DM}=234 \mathrm{x}\left(\mathrm{R}^{2}=0.84\right)$. Tall fescue based pastures did not fit with this established relationship for the harvest made on $13 / 10 / 2006$ and required a separate calibration of $\mathrm{DM}=49.8 \mathrm{x}$. This probably resulted from the unplanned grazing that resulted in a lower residual or slower recovery from grazing in the tall fescue based pastures. For non destructive DM determinations, 20 plate meter measurements were taken in each of the 48 plots. These values were averaged and converted to pasture height (cm) prior to conversion to DM yield using the calibration equations.

\section{Analysis}

Analyses were conducted with Genstat 9 for the strip plot design. Total DM yields were normally distributed and did not require transformation. Yields of individual pasture components were normalised by $\log$ transformation to ensure data met the requirement for unbiased analysis (Dytham 1999). As $\log 0$ is undefined, data were transformed using the equation $\mathrm{y}=\mathrm{Ln}(\mathrm{DM}+1)$. Fisher's protected LSD was used to separate transformed means when the ANOVA was significant. For interactions, the most conservative LSD was used for means separation. All data are presented as arithmetic treatment means of untransformed data but tests of significance were performed on transformed data.

\section{Results}

At the first harvest $(17 / 1 / 2006)$ there were no interactions or effects of treatment on total yield with $3960 \pm 894 \mathrm{~kg} \mathrm{DM} / \mathrm{ha}$ in all pastures but botanical composition differed between treatments (Table 1). The sown grass component of perennial ryegrass based pastures was more $(\mathrm{P} \leq 0.05)$ than double that of tall fescue and almost 10 times that produced by cocksfoot. Grass yield declined $(\mathrm{P} \leq 0.05)$ from $468 \mathrm{~kg} \mathrm{DM} / \mathrm{ha}$ for pastures sown without a cover crop to $56.4 \mathrm{~kg} \mathrm{DM} / \mathrm{ha}$ in pastures sown with rape at $3.0 \mathrm{~kg} / \mathrm{ha}$.

Rape yield more than doubled $(\mathrm{P} \leq 0.001)$ when sowing rate was increased from $0.5 \mathrm{~kg} / \mathrm{ha}$ to 1.5 or 3.0 $\mathrm{kg} / \mathrm{ha}$. The brassica represented $30 \%$ of total DM yield of pastures sown with $0.5 \mathrm{~kg} / \mathrm{ha}$ of rape compared with $70 \%$ of total yield in pastures with 1.5 or $3.0 \mathrm{~kg} / \mathrm{ha}$. Clover yield was similar in pastures sown with rape at 0 and $0.5 \mathrm{~kg} / \mathrm{ha}$ but decreased $(\mathrm{P} \leq 0.05)$ from $719 \mathrm{~kg} \mathrm{DM} /$ ha with no rape to $165 \mathrm{~kg} \mathrm{DM} / \mathrm{ha}$ in pastures which included $3.0 \mathrm{~kg} / \mathrm{ha}$ of rape. Of the clovers, white clover 
Table 1 Yield (kg DM/ha) of pasture components on 17/1/2006 at Darfield, Canterbury, for undersown dryland pastures established after forest conversion. Clovers represent total clover yield from white and red clovers and herbs includes yield from chicory and plantain.

\begin{tabular}{|c|c|c|c|c|c|c|c|c|}
\hline & & Grass & Rape & Clovers & Herbs & Weed & Dead & Total yield \\
\hline Species & $\begin{array}{l}\text { RG } \\
\text { TF } \\
\text { CF }\end{array}$ & $\begin{array}{l}466_{a} \\
207_{\text {ab }} \\
49.2_{b}\end{array}$ & $\begin{array}{c}1920 \\
2030 \\
1110\end{array}$ & $\begin{array}{l}258 \\
439 \\
608\end{array}$ & $\begin{array}{l}138 \\
121 \\
174\end{array}$ & $\begin{array}{c}613 \\
852 \\
1380\end{array}$ & $\begin{array}{l}635_{a} \\
537_{a b} \\
344_{b}\end{array}$ & $\begin{array}{l}4030 \\
4190 \\
3670\end{array}$ \\
\hline \multicolumn{2}{|c|}{ Significance } & * & NS & NS & NS & NS & * & NS \\
\hline Rape (kg/ha) & $\begin{array}{r}0 \\
0.5 \\
1.5 \\
3.0\end{array}$ & $\begin{array}{c}468_{\mathrm{ab}} \\
301_{\mathrm{a}} \\
63.5_{\mathrm{bc}} \\
56.4_{\mathrm{c}} \\
\end{array}$ & $\begin{array}{c}0_{c} \\
1120_{b} \\
2680_{a} \\
2430_{a b}\end{array}$ & $\begin{array}{l}719^{a} \\
492_{a b}^{a b} \\
228_{b}^{b} \\
165_{b} \\
\end{array}$ & $\begin{array}{l}218^{a} \\
225^{a} \\
63.6_{b}^{b} \\
26.1_{c} \\
\end{array}$ & $\begin{array}{c}1660_{\mathrm{a}} \\
1170_{\mathrm{ab}} \\
291_{\mathrm{b}} \\
384_{\mathrm{b}} \\
\end{array}$ & $\begin{array}{l}236_{b} \\
395^{a} \\
598_{a}^{a} \\
636_{a}\end{array}$ & $\begin{array}{l}3300 \\
3710 \\
3930 \\
3700\end{array}$ \\
\hline Signif & ance & * & $\star * \star$ & * & 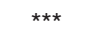 & * & $\star \star$ & NS \\
\hline
\end{tabular}

NOTE: Levels of significance are: ${ }^{*}=\mathrm{P} \leq 0.05,{ }^{* *}=\mathrm{P} \leq 0.01,{ }^{* * *}=\mathrm{P} \leq 0.001$ and $\mathrm{NS}=$ non significant. Numbers followed by the same letter are similar at the $\mathrm{P}<0.05$ level of significance. Analysis for total $\mathrm{DM}$ yield was performed on untransformed data. For botanical composition data, treatment effects were determined from log transformed data but values presented are arithmetic means of raw data.

Table 2 Yield (kg DM/ha) of pasture components on 3/5/2006 at Darfield, Canterbury, for undersown dryland pastures established after forest conversion. Clovers represents total clover yield $(\mathrm{kg} \mathrm{DM} / \mathrm{ha})$ from white and red clovers and herbs includes yield from chicory and plantain.

\begin{tabular}{|c|c|c|c|c|c|c|c|c|}
\hline & & Grass & Rape & Clovers & Herbs & Weed & Dead & Total yield \\
\hline \multirow[t]{3}{*}{ Species } & $R G$ & 480 & 326 & 267 & 101 & 34.7 & 267 & 1480 \\
\hline & $\mathrm{TF}$ & $358^{a}$ & 336 & 284 & 95.9 & 34.7 & 205 & 1310 \\
\hline & $\mathrm{CF}$ & $123_{b}^{a}$ & 211 & 375 & 168 & 87.1 & 199 & 1160 \\
\hline \multicolumn{2}{|c|}{ Significance } & ** & NS & NS & NS & NS & NS & NS \\
\hline \multirow[t]{4}{*}{ Rape (kg/ha) } & 0 & 438 & $0_{c}$ & 362 & 131 & 44.9 & 235 & 1210 \\
\hline & 0.5 & 290 & $239_{b}^{c}$ & 270 & 139 & 57.3 & 191 & 1190 \\
\hline & 1.5 & 259 & $257_{b}^{\circ}$ & 236 & 135 & 45.5 & 204 & 1140 \\
\hline & 3.0 & 196 & $578_{a}^{\circ}$ & 272 & 43.9 & 45.0 & 198 & 1330 \\
\hline \multicolumn{2}{|c|}{ Significance } & NS & $\star \star \star *$ & NS & NS & NS & NS & NS \\
\hline
\end{tabular}

NOTE: Levels of significance are: ${ }^{*}=\mathrm{P} \leq 0.05,{ }^{* *}=\mathrm{P} \leq 0.01,{ }^{* * *}=\mathrm{P} \leq 0.001$ and $\mathrm{NS}=$ non significant. Numbers followed by the same letter are similar at the $\mathrm{P}<0.05$ level of significance. Analysis for total DM yield was performed on untransformed data. For botanical composition data, treatment effects were determined from log transformed data but values presented are arithmetic means of raw data.

represented $58 \%$ of total clover yield. The herb (chicory and plantain) yield was suppressed $(\mathrm{P} \leq 0.001)$ by the inclusion of rape at 1.5 and $3.0 \mathrm{~kg} / \mathrm{ha}$ (Table 1). Rape inclusion at $>0.5 \mathrm{~kg} /$ ha reduced chicory content whereas plantain yield was only suppressed when rape was sown at $3.0 \mathrm{~kg} / \mathrm{ha}$.

Weed content was $\leq 10 \%$ in pastures sown with rape at 1.5 or $3.0 \mathrm{~kg} / \mathrm{ha}$ compared with $32 \%$ in pastures sown with rape at $0.5 \mathrm{~kg} / \mathrm{ha}$ and $50 \%$ of total DM yield when rape was not included $(\mathrm{P} \leq 0.05)$ in the pasture mix. During the course of measurements, the two dominant weed species at the site were fathen and sorrel. Surprisingly, woody weeds contributed minimally to total DM yield.

There was an interaction $(\mathrm{P} \leq 0.05)$ between grass species and rape sowing rate in the amount of dead material in the pastures (data not presented). This was primarily caused by low amounts of dead material in cocksfoot pastures sown with no rape. In all other pastures the dead material ranged from $207 \mathrm{~kg} \mathrm{DM} / \mathrm{ha}$ (tall fescue pastures with no cover crop) to $873 \mathrm{~kg} \mathrm{DM} /$ ha for perennial ryegrass.

For the second harvest, in autumn, (3/5/2006) all pastures produced about $1320 \pm 261 \mathrm{~kg} \mathrm{DM} / \mathrm{ha}$ and this was unaffected by treatment (Table 2). The grass yield from both perennial ryegrass $(480 \mathrm{~kg} \mathrm{DM} / \mathrm{ha})$ and tall fescue ( $358 \mathrm{~kg} \mathrm{DM} / \mathrm{ha})$ was greater $(\mathrm{P} \leq 0.01)$ than from cocksfoot (123 kg DM/ha). Rape regrowth was affected $(\mathrm{P} \leq 0.001)$ by sowing rate and increased from $20-23 \%$ of total DM yield, in pastures sown with rape at 0.5 and $1.5 \mathrm{~kg} \mathrm{DM} / \mathrm{ha}$ to $43 \%$ of total yield when rape was sown at $3.0 \mathrm{~kg} / \mathrm{ha}$. Overall, weed components were $<4 \%$ of total DM yield in all pastures and unaffected by treatments. Total legume yield was between 200 and 500 $\mathrm{kg} \mathrm{DM} / \mathrm{ha}$ and represented $\sim 24 \%$ of total DM in all pastures.

Total DM yield for the early spring rotation (4/8/2006$13 / 10 / 2006)$ was affected $(\mathrm{P} \leq 0.001)$ by grass species with $1990 \mathrm{~kg} \mathrm{DM} /$ ha produced by perennial ryegrass based pastures compared with $1470 \mathrm{~kg} \mathrm{DM} / \mathrm{ha}$ for 
Table 3 Total DM yields (kg DM/ha) for rotations ending 13/10/2006, 19/12/2006 and 16/2/2005 at Darfield, Canterbury, for undersown dryland pastures established after forest conversion.

\begin{tabular}{|c|c|c|c|c|}
\hline & & $13 / 10 / 2006$ & $19 / 12 / 2006$ & $16 / 2 / 2007$ \\
\hline \multicolumn{5}{|l|}{ Species } \\
\hline & $\begin{array}{l}\mathrm{RG} \\
\mathrm{TF} \\
\mathrm{CF}\end{array}$ & $\begin{array}{c}1990^{a} \\
334_{c} \\
1470_{b}\end{array}$ & $\begin{array}{l}2810 \\
2460 \\
2490\end{array}$ & $\begin{array}{l}2720 \\
2290 \\
2680\end{array}$ \\
\hline \multicolumn{2}{|c|}{ Significance } & $* * *$ & NS & NS \\
\hline Rape (kg/ha) & $\begin{array}{r}0 \\
0.5 \\
1.5 \\
3.0\end{array}$ & $\begin{array}{l}1460 \mathrm{a} \\
1360_{\mathrm{a}} \\
1130_{\mathrm{b}} \\
1100_{\mathrm{b}}\end{array}$ & $\begin{array}{l}2760 \text { a } \\
2680_{a}^{a} \\
2450 b \\
2450 \text { b }\end{array}$ & $\begin{array}{l}2710 \\
2520 \\
2450 \\
2560\end{array}$ \\
\hline \multicolumn{2}{|c|}{ Significance } & ** & * & NS \\
\hline
\end{tabular}

NOTE: Levels of significance are: ${ }^{*}=\mathrm{P} \leq 0.05,{ }^{* *}=\mathrm{P} \leq 0.01,{ }^{* * *}=\mathrm{P} \leq 0.001$ and $\mathrm{NS}=$ non significant. Numbers followed by the same letter are similar at the $\mathrm{P}<0.05$ level of significance.

cocksfoot pastures and $334 \mathrm{~kg} \mathrm{DM} / \mathrm{ha}$ for tall fescue (Table 3). In addition, rape sowing rate affected $(\mathrm{P} \leq 0.01)$ total DM yield with pastures sown with rape at 0 and 0.5 $\mathrm{kg} /$ ha producing $26 \%$ more total DM than pastures sown with rape at 1.5 or $3.0 \mathrm{~kg} / \mathrm{ha}$. Botanical composition was measured from replicate 1 and is shown in Figure 2. By this and subsequent harvests, rape represented $<5 \%$ of total DM yield. White clover represented $35-75 \%$ of the spring legume yield and $14-50 \%$ of total DM yield.

In Year 2 the spring rotation (ending 19/12/2006) showed pastures established with rape at 1.5 or $3.0 \mathrm{~kg} /$ ha produced $2450 \pm 2.00 \mathrm{~kg} \mathrm{DM} / \mathrm{ha}$ which was less $(\mathrm{P} \leq 0.05)$ than the $2720 \pm 43.0 \mathrm{~kg} \mathrm{DM} / \mathrm{ha}$ in pastures sown with rape at 0 or $0.5 \mathrm{~kg} / \mathrm{ha}$ (Table 3 ). Botanical composition was not determined at this harvest. For the summer regrowth cycle (ending 16/2/2007) yield was $2560 \pm 468 \mathrm{~kg} \mathrm{DM} / \mathrm{ha}$ in all pastures and was unaffected by treatment. Botanical composition, determined from replicate 1, is shown in Figure 3. At this time, the clovers represented $60 \%$ of total DM yield and $70-95 \%$ of this total legume was from red clover.

\section{Discussion}

As expected in forestry conversions, the experimental site was highly variable particularly in areas that were formerly windrows. This variability affected the uniformity of plots and consequently the ability to detect significant differences. Despite this, several key results were apparent for dryland forest conversion, particularly when using slow establishing pasture species.

Specifically, Table 1 showed total DM yield at the first harvest (17/1/2006) was not affected by grass species or rape sowing rate, but rape rate did affect pasture composition. The value of the cover crop for weed suppression was shown as $50 \%$ of total DM yield, or $1660 \mathrm{~kg} \mathrm{DM} / \mathrm{ha}$, contributed by weeds in pastures established without a cover crop compared with $\leq 10 \%$ $(<400 \mathrm{~kg} \mathrm{DM} / \mathrm{ha})$ in pastures which included rape at 1.5 or $3.0 \mathrm{~kg} / \mathrm{ha}$. Yields of grass, legume and herb components were all reduced by the inclusion of rape at 1.5 or $3.0 \mathrm{~kg} /$ ha (Table 1). Pasture species affected sown grass yield with perennial ryegrass production more than double that of tall fescue and 10 times that of the cocksfoot. This advantage in perennial ryegrass production is consistent with its low thermal time requirements for germination and establishment and high seedling vigour even in dry conditions (McWilliam et al. 1970).

The suppression of white clover by rape was shown by the reduction of clover from $22 \%$ of the pasture when no rape was included to $<5 \%$ when $3.0 \mathrm{~kg} / \mathrm{ha}$ of rape was used. This is consistent with reports that white clover is less competitive than other species (Cullen 1964). Similar trends were observed for the grass and herb components. The inclusion of rape as a cover crop at 1.5 or $3.0 \mathrm{~kg} / \mathrm{ha}$ produced $2560 \pm 127 \mathrm{~kg} \mathrm{DM} / \mathrm{ha}$ with no additional DM yield from the high rape sowing rate. The lack of perennial woody weeds, specifically gorse and broom, at this site was unexpected, particularly because 40 gorse seedlings $/ \mathrm{m}^{2}$ were counted at an adjacent site prior to pasture establishment (Edwards et al. 2007). The lack of woody weeds reflects their slow growth and consequently their low contributions to total DM yield. Hard grazing has been recommended for gorse suppression during pasture establishment and lime application is also known to suppress gorse (Edwards et al. 2007: Hartley \& Phung 1979).

By the second harvest, total yield and contributions from clover, herbs, weed and dead fractions were similar (Table 2). The inclusion of $1.5 \mathrm{~kg} / \mathrm{ha}$ of rape was sufficient to continue suppression of weeds and maintain pasture yield at this dryland ex-forestry site although this differed between grass species. The yield of the slower establishing cocksfoot (Moot et al. 2000) was lower than the other grass species which probably contributed to the increased $(\mathrm{P}<0.10)$ clover and weed content in these pastures. Rape regrowth from pastures established 
Figure 2 Grass $(\square)$, brassica $(\mathbb{\mathbb { Q }})$, clover $(\square)$, herb $(\mathbb{U})$, weed $(\mathbb{Q})$ and dead $(ख)$ DM yields, on 13/10/2006 in replicate 1, of perennial ryegrass, tall fescue or cocksfoot based pastures sown in combination with rape at $0,0.5,1.5$ or $3.0 \mathrm{~kg} / \mathrm{ha}$ for undersown dryland pastures established after forest conversion.

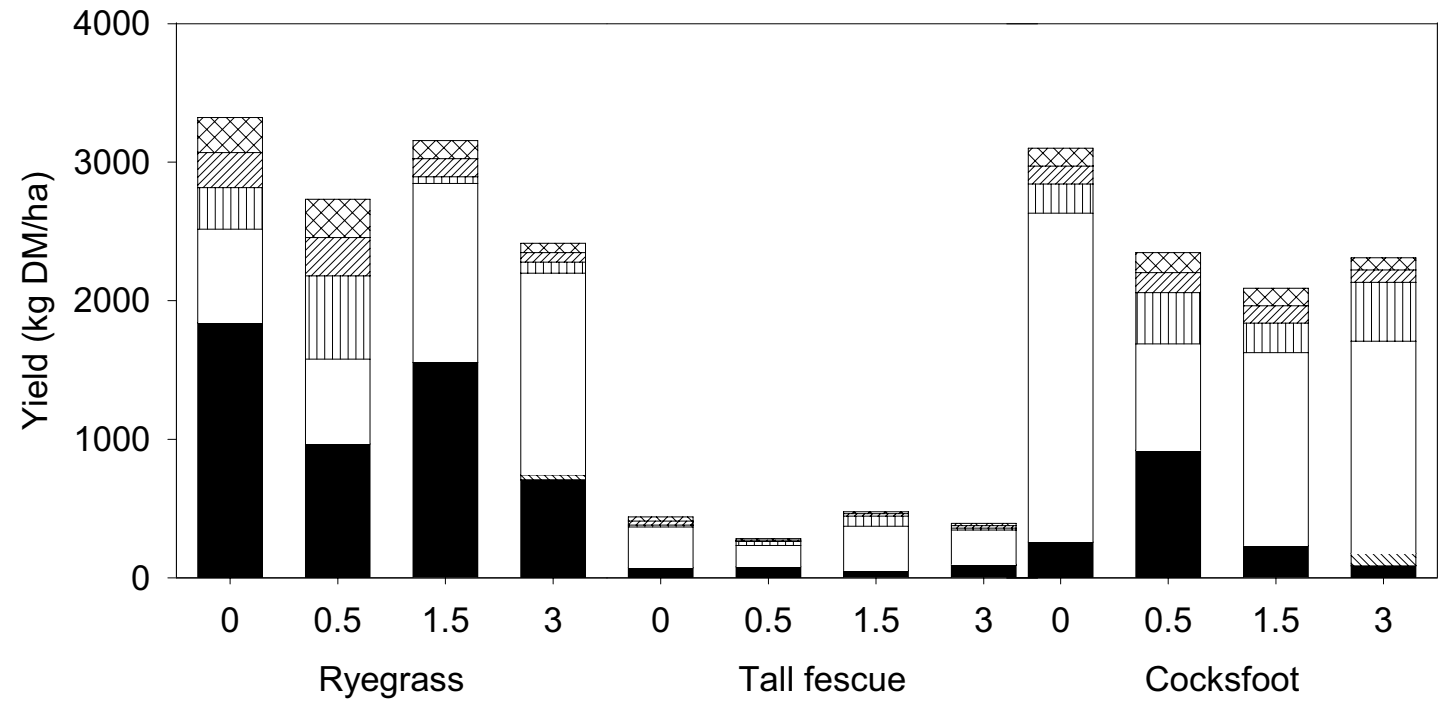

Figure 3 Grass ( $\square$ ), clover $(\square)$, herb (四), weed (因) and dead (国) DM yields of perennial ryegrass, tall fescue or cocksfoot pastures sown in combination with rape at $0,0.5,1.5$ or $3.0 \mathrm{~kg} / \mathrm{ha}$ on 16/2/2007 from replicate 1 for undersown dryland pastures established after forest conversion.

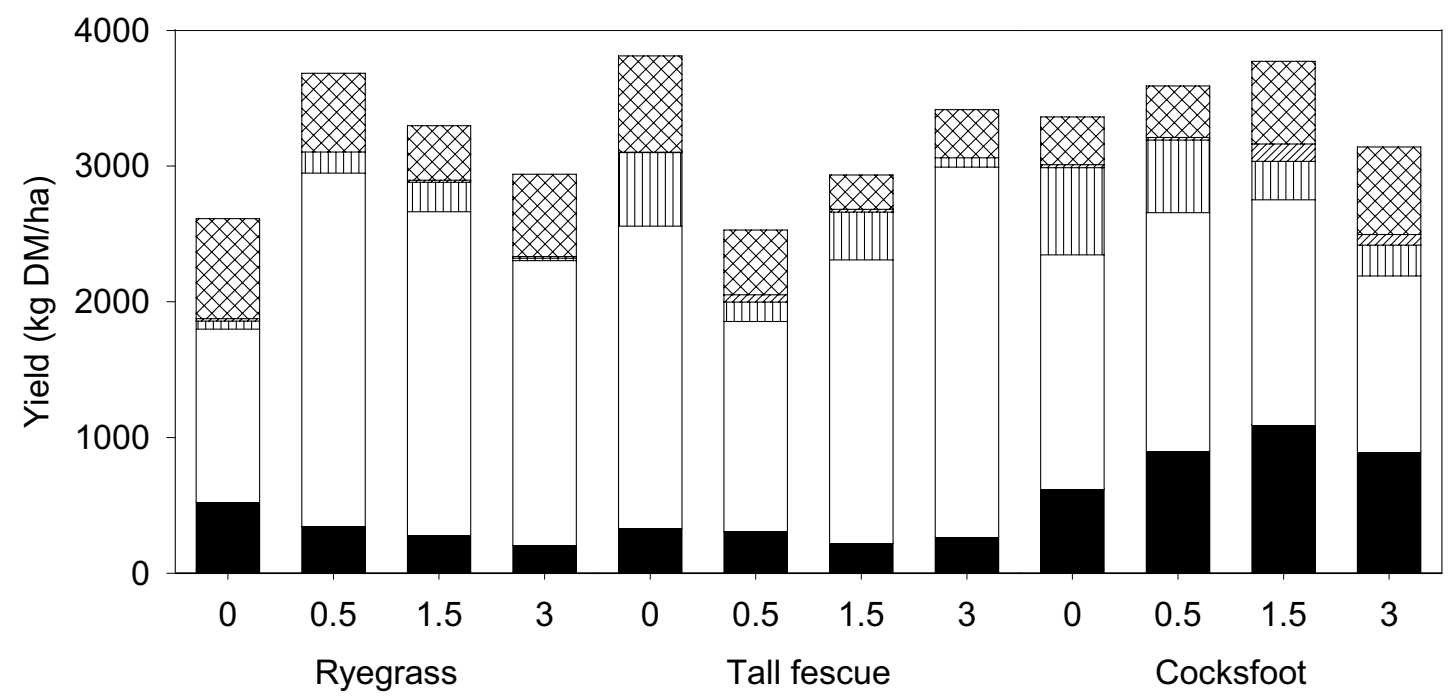

with $3.0 \mathrm{~kg} / \mathrm{ha}$ of rape was $578 \mathrm{~kg} \mathrm{DM} /$ ha or double that from the other treatments. Beyond this harvest, the rape contribution to total yield was negligible.

An indication of seasonal differences in species productivity can be seen from the spring and summer harvests. The yield and composition of the third harvest were affected by the unplanned grazing during winter. However, the early spring advantage of the perennial ryegrass and white clover, which represented $63 \%$ of the total legume yield, is illustrated in Figure 2. Equally the composition from replicate 1 of the summer harvest
(Fig. 3) shows cocksfoot had the highest grass yield, and the tap rooted red clover dominated the legume and herb component. The low $(<5 \%)$ weed component in all pastures reflects the annual nature of the main weed species (fathen) at this site.

The sown grasses represented $\leq 50 \%$ of the total DM yield at all harvests. This probably reflects the lack of available nitrogen in the system immediately after the removal of trees and the high wood content, meaning $\mathrm{N}$ is immobilised during decomposition due to a high $\mathrm{C}: \mathrm{N}$ ratio (Condron et al. 2007). Typically, cultivated soils 
will release nitrogen that can result in establishing pastures being grass dominant. In contrast, these pastures were legume dominant, initially with white clover and then, after about 12 months, with red clover. Over time the red clover will decline as it generally only persists for 2-5 years (Brown et al. 2005). Pastures may then require either high fertiliser nitrogen inputs or potentially direct drilling of annual clovers to maintain productivity.

The use of perennial ryegrass may not be suitable for the shallow stony soils of ex-forestry sites as it is unlikely to persist and recover from summer drought conditions as successfully as tall fescue or cocksfoot based pastures (Charlton \& Stewart 1999; Stevens \& Hickey 2000). It is likely that perennial ryegrass yields would be compromised over summer months in an average year as the soil moisture deficit developed (Korte \& Chu 1983). Due to the spring sowing, annual clovers were not included in pastures but this may be an alternative option for weed suppression in autumn sown pastures established after the removal of forests. Regardless, this experiment has shown that when a slow establishing species is selected to ensure long term pasture productivity it is important to use a cover crop to reduce competition from weed species.

\section{Conclusions}

- Total DM production was similar in all pastures at the first two harvests and the inclusion of rape at $\geq 1.5$ $\mathrm{kg} / \mathrm{ha}$ reduced weed content during pasture establishment while maintaining total yield.

- Brassica yield at the first harvest was similar for pastures which included rape at 1.5 and $3.0 \mathrm{~kg} / \mathrm{ha}$.

\section{ACKNOWLEDGEMENTS}

Selwyn Plantation Board Ltd provided funding for this research. Meat \& Wool New Zealand Ltd for support of A. Mills in writing up this work.

\section{REFERENCES}

Baker, D.J.; Chu, A.C.P.; Korte, C.J. 1985. Some effects of spring defoliation and drought on perennial ryegrass swards. Proceedings of the New Zealand Grassland Association 46: 57-63.

Brown, H.E.; Moot, D.J.; Pollock, K.M. 2005. Herbage production, persistence, nutritive characteristics and water use of perennial forages grown over 6 years on a Wakanui silt loam. New Zealand Journal of Agricultural Research 48: 423-429.

Cayley, J.W.D.; Bird, P.R. 1996. Techniques for Measuring Pastures (2nd Ed). Hamilton, Vic.: Pastoral and Veterinary Institute. $51 \mathrm{pp}$.

Charlton, J.F.L.; Stewart, A.V. 1999. Pasture species and cultivars in New Zealand - a list. Proceedings of the New Zealand Grasslands Association 61: 147-
166.

Condron, L.R.; Moot, D.J.; Marshall, A.J; White, P.J.; Edwards, G.R. 2007. Forage responses to lime and nitrogen fertiliser on land converted from pine forest to dryland pasture in Canterbury. Proceedings of the New Zealand Grasslands Association 69: 111-115.

Cullen, N.A. 1964. The effect of nurse crops on the establishment of pasture. I. Rape (Brassica napus L.) forage crop. New Zealand Journal of Agricultural Research 7: 42-51.

Dytham, C. 1999. Choosing and using statistics: a biologists guide. Blackwell Publishing, UK. 247 pp.

Edwards, G.R.; Tozer, K.N.; Maxwell, T.M.R.; Marshall, A.J. 2007. Control of gorse (Ulex europaeus) in dryland pasture converted from Pinus radiata forest. New Zealand Plant Protection 60: 141-145.

Hartley, M.J.; Phung, H.T. 1979. Effect of pasture species and grazing on survival of seedling gorse. pp 193196. In: Proceedings of the 32nd New Zealand Weed and Pest Control Conference.

Keoghan, J.; Allan, B. 1992. Pasture species for tussock grassland landscapes and farming systems. pp 39-54 In: Guide to Tussock Grassland Farming. Ed. Floate, M. AgResearch, Invermay, Dunedin.

Knowles, I.M.; Fraser, T.J.; Daly, M.J. 2003. White clover: loss in drought and subsequent recovery. Legumes for dryland pastures. Grassland Research and Practice Series 11: 37-41.

Korte, C.J.; Chu, A.C.P. 1983. Some effects of drought on perennial ryegrass swards. Proceedings of the New Zealand Grassland Association 44: 211-216.

McWilliam, J.R.; Clements, R.J.; Dowling, P.M. 1970. Some factors influencing the germination and early seedling development of pasture plants. Australian Journal of Agricultural Research 21: 19-32.

Moot, D.J.; Mills, A.; Marshall, A.; Edwards, G.R. 2007. Lucerne establishment sequences to maximise weed control in ex Pinus radiata plantations. Proceedings of the New Zealand Grasslands Association 69: 99115.

Moot, D.J.; Scott, W.R.; Roy, A.M.; Nicholls, A.C. 2000. Base temperature and thermal time requirements for germination and emergence of temperate pasture species. New Zealand Journal of Agricultural Research 43: 15-25.

Petersen, R.G. 1985. Design and analysis of experiments. Marcel Dekker, Inc, New York. 429 pp.

Stevens, D.R.; Hickey, M.J. 2000. Effects of binary seed mixtures of ryegrass, cocksfoot and tall fescue on pasture production. Proceedings of the New Zealand Grassland Association 62: 141-146.

Wynn-Williams, R.B. 1976. Lucerne establishment. 2. Cover crops and lucerne establishment. New Zealand Journal of Experimental Agriculture 4: 171-175. 